v. $12, n .4$

Vitória-ES, Jul.-Aug. 2015

p. $79-98$ ISSN 1808-2386

DOI: http://dx.doi.org/10.15728/bbr.2015.12.4.4

\title{
Construction of Meaning of the Undergraduate Course in Business Administration by High and Low Income Students
}

\author{
Marcelo de Rezende Pinto ${ }^{\dagger}$ \\ Pontifical Catholic University of Minas Gerais \\ Marcos Eugênio Vale Leão ${ }^{\Omega}$ \\ Newton Paiva University Center \\ Ramon Silva Leite ${ }^{¥}$ \\ Pontifical Catholic University of Minas Gerais \\ Danielle Ramos de Miranda Pereira ${ }^{ \pm}$ \\ João Pinheiro Foundation
}

\begin{abstract}
This paper reports the results of an empirical study undertaken with a sample of 368 undergraduate business administration students from five private universities in a large Brazilian city. The objective was to analyze the differences in perceptions of the course by students from high and low income backgrounds regarding the following issues: the cultural and symbolic elements involving higher education; the relevance of higher education in consumer priorities and the influence on consumption behavior of students; the appropriateness of the course to their reality; and the expected benefits of obtaining a degree. The data were analyzed using the Grade of Membership (GoM) and t-test statistical techniques. The results, which were compared with the theoretical framework on consumption in a cultural and symbolic perspective, signaled there is a difference in meaning between the two groups of students.
\end{abstract}

Keywords: Undergraduate business administration course. Low-income students. Consumption.

Received in 10/22/2013; accepted in 03/10/2014; disclosed in 07/01/2015

\begin{tabular}{|c|c|c|}
\hline & & ${ }^{\ddagger} \mathrm{PhD}$ in Business Administration \\
\hline $\begin{array}{l}\dagger \mathrm{PhD} \text { in Business } \\
\text { Administration from } \\
\text { CEPEAD/UFMG } \\
\text { Institution: Assistant } \\
\text { Professor at Pontifical } \\
\text { Catholic University of } \\
\text { Minas Gerais } \\
\text { Address: Av. Itaú, } \\
\text { Bairro Dom Cabral - } \\
\text { Belo Horizonte - MG } \\
\text { - Brazil - E-mail: } \\
\text { marcrez@ @otmail.com } \\
\text { Telephone: (31) 3319- } \\
4957\end{array}$ & $\begin{array}{l}\Omega \text { Master's in Business } \\
\text { Administration from } \\
\text { FEAD/MG } \\
\text { Institution: Professor at the } \\
\text { Newton Paiva University } \\
\text { Center } \\
\text { Address: Rua dos } \\
\text { Goitacazes, Bairro Preto, } \\
\text { Belo Horizonte - MG - } \\
\text { Brazil } \\
\text { E-mail: } \\
\text { leaovale@ gmail.com } \\
\text { Telephone: (31) 3295-6210 }\end{array}$ & $\begin{array}{l}\text { from Mackenzie Presbyterian } \\
\text { University } \\
\text { Institution: Assistant Professor at } \\
\text { Pontifical Catholic University of } \\
\text { Minas Gerais } \\
\text { Address: Av. Itaú, Bairro Dom } \\
\text { Cabral - Belo Horizonte - MG } \\
\text { - Brazil - E-mail: } \\
\text { ramonsl@pucminas.br } \\
\text { Telephone: (31) 3319-4957 }\end{array}$ \\
\hline
\end{tabular}

† PhD in Demography from

CEDEPLAR/UFMG

Institution: Researcher at the Center for Public Policy Studies of João Pinheiro Foundation

Address: Alameda das Acácias,

Bairro São Luiz - Belo Horizonte

- MG - Brazil

E-mail:

danielle.pereira@fjp.mg.gov.br

Telephone: (31) 3448-9424

Note from the Editor: The article was accepted by Emerson Mainardes. 


\section{INTRODUCTION}

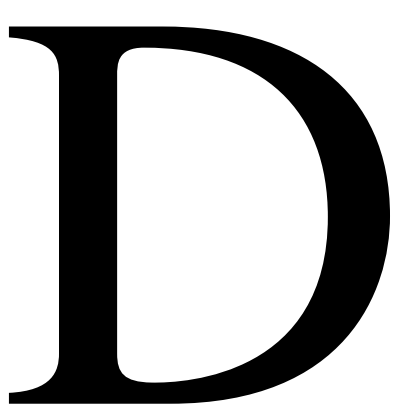

iscussions involving questions related to business administration courses as well as students' perceptions of the course, the teaching institution and the career and profession of business manager are not new in the Brazilian academic context. Proof of this is that for years there has been a space dedicated to discussions of these themes at the annual meetings of the National Association of Graduate Administration Programs and Research (ANPAD). Hence, many studies have been conducted in recent years on this theme.

On the matter of students' perceptions of business administration programs, a large portion of the studies follow a line aimed at understanding the course as provision of a service. In other words, the authors seek to shed light on the quality of the services rendered by teaching institutions in terms of faculty, infrastructure (library, classrooms, research facilities and socializing centers), as well as services of the dean's office and support services, among others (SOUKI; PEREIRA, 2004; NICOLAO; SPARTEL, 2004; CODA; SILVA, 2004; VELUDO-DE-OLIVEIRA; IKEDA, 2006; ARAÚJO et al., 2010; MAINARDES; DOMINGUES, 2010; BERGAMO; GIULIANI; GALLI, 2011; TONTINI; WALTER, 2011; LOURENÇO; KNOP, 2011; MENDONÇA et al., 2012) or the value perceived by consumers of business administration programs (BORINI; SILVA; PONCHIP, 2009).

Other works seek "bridges" with other academic disciplines or fields of knowledge (AQUINO; TOMASSINI, 2009; LOMBARDI; ARAÚJO; TEIXEIRA, 2009). It is also possible to find studies focused on the motivation of students to choose business administration as a major (MIRANDA; SILVA, 2003; SILVA; MACHADO, 2006; CAMARGOS et al., 2008; FALCÃO; ROSA, 2008; BOMTEMPO; SILVA; FREIRE, 2012), and studies of their conception of the course in light of a critical approach (BATISTA-DOSSANTOS et al., 2011).

Because of the context of higher learning in Brazil in recent decades, marked by greater flexibility in opening teaching institutions and a sharp increase in capacity and enrollments (FISCHER, 2000), two interrelated questions have gained importance regarding business administration programs. The first of them is the flow of students with increasingly heterogeneous origin, economic class, family income/situation and previous education. The second is the expansion of government programs to provide financial support to students, enabling broader access to higher education. A third, tangential question, is the "trend" 
perceived in consumer studies in recent years to investigate the behavior and attitudes of a contingent of consumers called "popular", "poor" or "low income" (PRAHALAD; HAMMOND, 2002; PRAHALAD, 2005).

In light of this context, some specific questions emerge: To what measure do administration students perceive symbolic and cultural elements related to the degree program? What are the benefits they perceive of obtaining a degree? What are the most relevant aspects in the articulation between consumption and entry in the business administration course by these students? To what degree is the course suitable to the reality of these students? Are there differences in perception of meanings between students with different backgrounds? And more particularly, is there a difference in this perception between students with low-income backgrounds versus those from the middle and upper classes?

Because these questions are still relatively unexplored in Brazil, the purpose of this article is to analyze empirically the differences in perceptions of students with high and low income backgrounds regarding the following issues related to undergraduate study of business administration: the cultural and symbolic elements involving higher education, the relevance this education occupies in the consumption priorities and the influence on the consumption behavior of students, the adequacy of the course to their reality and the expected benefits of enrolling in an undergraduate administration course.

This paper is structured in five sections including this introduction. In the next section we succinctly review some points on the theme of consumption, with special emphasis on the scope of approaches, concepts and perspectives, and present some points regarding the cultural and symbolic perspective of consumption. In the third section we describe the methodology, and in the fourth we present the main results, before closing with some final reflections.

\section{CONSUMPTION: EXPANDING CONCEPTS, PERSPECTIVES AND APPROACHES}

Careful observation of consumption and its implications can lead to connections for a better understanding of various central elements of contemporary society (BARBOSA, 2006). Consumption can be seen as a social process involving multiple ways of providing goods and services and different forms of access to them. At the same time, it can be viewed as a social mechanism understood by the social sciences as a producer of meanings and identities, or as a strategy used in daily life by different social groups to define diverse situations in terms of rights, lifestyles and identities (BARBOSA; CAMPBELL, 2006; DESJEUX, 2011; 
MCCRACKEN, 2012). Hence, it is related to the way people want to live and questions involving how society is or should be organized, without speaking of the material and symbolic structure of the places we live and the way we interact in them.

Consumption has therefore become a complex, ambiguous and elusive field of investigation, since it now is perceived as encompassing various activities, actors and a set of goods and services that go beyond those supplied by traditional markets (BARBOSA; CAMPBELL, 2006). What can be said, for example, about consumption of activities that are intangible and "perishable", such as services in their various classifications and characteristics? And what about the consumption of meanings that are present in the "marketing" of ideas, places and organizations? In the same sense, what can be said about consumption of experiences such as entertainment, leisure and tourism activities? Since consumption is a eminently positive practice, one that produces imaginations and meanings articulated by consumers themselves, and considering that teaching activities also involve consumption, it is fitting to ask whether students also consume experiences in their daily contact with teaching institutions, teachers, administrative people and classmates, as well as with professionals of other areas and competencies.

The central idea of this study rests on the recognition of the growing complexity of consumption practices and the ways those practices, in equally complex manner, are involved in the daily lives of individuals (MILLER, 2002): the construction of meanings in the consumption experiences at teaching institutions, and more specifically, in relation to the business administration course.

In this respect, consumption can be understood as an eminently cultural phenomenon. In the first place, all consumption involves meaning. For individuals to "have needs" and act on them, they must be able to interpret sensations, experiences and situations while at the same time giving meaning to various objects, actions and resources in relation to these needs. In the second place, consumption is always cultural, because the meanings involved are shared, i.e., individuals' preferences are formed inside cultures. Thirdly, all forms of consumption are culturally specific. This means to say they are articulated according to or in relation to specific ways of living. Finally, it is through culturally specific forms of consumption that people re(produce) cultures, social relations and society itself. In other words, by knowing and using the codes of their culture, individuals reproduce and demonstrate their participation in a determined social order (SLATER, 2002). 


\section{METHODOLOGY OF THE EMPIRICAL STUDY}

The investigation was conducted in two overall steps: the first qualitative and exploratory in nature and the second with descriptive characteristics.

First Step: In-depth interviews, focus group discussion and consultation with specialists

In this step of the study, exploratory in nature, we aimed to create a knowledge base to construct the survey instrument (CHURCHILL JUNIOR, 1979; MALHOTRA, 2001). We first conducted a literature review (desk research) to map the studies previously conducted in Brazil involving business administration programs, especially students' perceptions about the course. Then one of us conducted in-depth interviews with 16 business administration students, to learn their perceptions about higher learning, their particular administration course and their relationship with the teaching institution.

This survey was conducted among students of a private university and the data were examined by the content analysis technique. In this phase, the following categories emerged from the interviews: articulation of professional, personal and academic life; characteristics of the course; daily classroom activities; teaching institution; family matters; relationships; and symbolisms. These categories helped in outlining the questions addressed in the focus group.

We then recruited a focus group (MORGAN, 1997) to identify and validate general elements pertinent to the students and to determine their perceptions about higher learning. The focus group was formed by ten students of both sexes enrolled in an undergraduate business administration course.

The discussion of this group, which was recorded and analyzed, gave rise to the following points:

Higher education and social recognition (family, friends, acquaintances and work colleagues);

$>$ Higher education and discrimination (discrimination against students from lower socioeconomic classes and discrimination for not having a college degree);

$>$ Price versus brand strength;

$>$ Higher education and personal expectations (professional perspectives, opportunities for women and higher learning, and quality of family life);

$>$ Higher education and personal spending; 
The role of teaching institutions (professional performance and construction of careers, teaching institutions and digital inclusion, reconciling class and job schedules, learning, tuition levels and payment schedules, entrepreneurship, continuity of studies).

The focus group discussion allowed refining the points originally listed by analyzing the response to the in-depth interviews, resulting in a scale composed of 56 items, grouped into four dimensions, as shown in table 1.

\begin{tabular}{|c|l|c|l|}
\hline DIMENSION & NAME & $\begin{array}{c}\text { NUMBER OF } \\
\text { ITEMS IN THE } \\
\text { SCALE }\end{array}$ & \multicolumn{1}{|c|}{ DESCRIPTION } \\
\hline Dimension 1 & $\begin{array}{l}\text { Cultural } \\
\text { influence and } \\
\text { symbolism }\end{array}$ & 15 & $\begin{array}{l}\text { Evaluate the cultural and symbolic elements } \\
\text { regarding access to higher education }\end{array}$ \\
\hline Dimension 2 & $\begin{array}{l}\text { Expected } \\
\text { benefits }\end{array}$ & 10 & $\begin{array}{l}\text { Identify the expectations generated by access to } \\
\text { higher education }\end{array}$ \\
\hline Dimension 3 & Relevance & 12 & $\begin{array}{l}\text { Determine the relevance of higher education in the } \\
\text { consumption priorities of the respondents }\end{array}$ \\
\hline Dimension 4 & $\begin{array}{l}\text { Adjustment to } \\
\text { reality }\end{array}$ & 19 & $\begin{array}{l}\text { Identify the adjustment of the private institutions to } \\
\text { the students' realities }\end{array}$ \\
\hline
\end{tabular}

Table 1 - Dimensions of the study

Source: Survey data (2012)

\section{Second step: Applying the Grade of Membership (GoM) and t-test techniques}

For this step of the study we performed an intersectional survey, since our aim was a description at a single point in time to determine the relationship between variables (BABBIE, 1999). The observation units were undergraduate business administration students (evening program) at five private institutions in a large Brazilian city (two universities, two university centers and one college). We used a non-probabilistic convenience sample combined with the technique that Babbie (1999) calls "reliance on available subjects". All told we obtained 411 completed questionnaires, of which 43 were considered invalid due to errors and unanswered questions, leaving 368 valid questionnaires. The questionnaire had been pre-tested with a group of 37 students at one of the institutions participating in the survey.

The questionnaire was divided into two parts. The first was to obtain personal data, such as sex, marital status, number of children, type of residence, monthly income, current 
position, level of the position and the items used by the Brazilian Association of Polling Firms (ABEP) to compose the Brazilian Economic Classification Criterion. The second part was composed of 56 questions scored on a five-point Likert scale (totally agree, partly agree, neutral, partly disagree, totally disagree).

Of the 56 questions in the survey, 20 were used to apply the GoM method. The questions used to delineate the students' profiles regarding their perception of the various aspects of the administration course and their influence on the students' consumption behavior are depicted in table 2 .

To analyze the data, we applied a factor analysis technique involving latent class analysis, known as Grade of Membership (GoM), since the objective was to delineate profiles of business administration students based on observed nominal or ordinal variables, seeking to estimate a latent categorical factor.

This method is based on fuzzy sets theory (or fuzzy logic), in which each respondent can have a certain degree of pertinence in multiple sets, unlike many other statistical techniques. According to Tam and Borges (2002), fuzzy logic is based on the concept of imprecise subsets, resulting from the fact that the classes of objects found in nature often do not have clearly defined membership criteria.

\begin{tabular}{|c|c|}
\hline NUMBER & DESCRIPTION OF THE QUESTION \\
\hline 1 & $>$ Economic class \\
\hline 2 & $>$ Household income \\
\hline 3 & $>$ I see higher education as an opportunity to rise socially. \\
\hline 4 & $\begin{array}{l}\text { With a college degree, I'll have better professional opportunities in the market than I } \\
\text { currently do at the company where I work. }\end{array}$ \\
\hline 5 & $\begin{array}{l}\text { With a college degree I hope to increase my income and buy products and services that I } \\
\text { can't afford now. }\end{array}$ \\
\hline 6 & $\begin{array}{l}\text { My current job is limited and offers little opportunity for professional growth. A college } \\
\text { degree is an alternative to find a new job with another company and hold positions with } \\
\text { higher pay and status. }\end{array}$ \\
\hline 7 & $\begin{array}{l}\text { Because of my study, I've had to reduce spending on the quantity and variety of foods } \\
\text { consumed at home. }\end{array}$ \\
\hline 8 & $>$ My spending on eating out has declined because of my school expenses. \\
\hline 9 & $\begin{array}{l}\text { I consider it a priority to allocate my income to a college program instead of to use it to } \\
\text { buy a car. }\end{array}$ \\
\hline 10 & $>$ I've had to forgo buying clothes and accessories because of my school expenses. \\
\hline 11 & $\begin{array}{l}\text { I've had to reduce my spending on preventive health care, such as doctor's office visits, } \\
\text { health plans (individual plans) and dental treatments because of my school expenses. }\end{array}$ \\
\hline
\end{tabular}




\begin{tabular}{|c|c|}
\hline 12 & $\begin{array}{l}\text { I've had to reduce my spending on travel, movies, restaurants, bars and diversion in } \\
\text { general because of my school expenses. }\end{array}$ \\
\hline 13 & $\begin{array}{l}\text { My purchase of modern electrical equipment has been restricted because of my school } \\
\text { expenses. }\end{array}$ \\
\hline 14 & $\begin{array}{l}\text { I have problems keeping up with my studies because of the low quality of my high } \\
\text { school. }\end{array}$ \\
\hline 15 & $>$ Commuting to and from school represents a substantial portion of by monthly budget. \\
\hline 16 & $\begin{array}{l}\text { The meals/snacks sold at my school are very expensive and eating them every day is } \\
\text { outside my budget. }\end{array}$ \\
\hline 17 & $>$ I've already made tuition payments late because of financial difficulties. \\
\hline 18 & $\begin{array}{l}\text { My access to the internet, computers and technology in general at my school is restricted, } \\
\text { which impedes my personal and professional development. }\end{array}$ \\
\hline 19 & $>$ If I lose my job, I'll have to take a leave of absence from my school. \\
\hline 20 & $\begin{array}{l}\text { I sense a lack of job placement programs at my school to enable me to find a good job } \\
\text { and to promote my professional career. }\end{array}$ \\
\hline
\end{tabular}

Table 2 - Questions used to delineate the profiles

Source: Survey data (2012)

Various studies have been conducted in Brazil applying the GoM method to delineate profiles, especially in the areas of demography (MACHADO, 1997; SAWYER et al., 2000; SAWYER et al., 2002; CERQUEIRA; SAWYER, 2004; CAETANO; MACHADO, 2009), public health (ALVES; LEITE; MACHADO, 2008; CARDOSO et al., 2011) and business administration (TAM; BORGES, 2002; PEREIRA; PINTO, 2004; PINTO; PEREIRA; SANTOS, 2007).

The GoM method, besides enabling analysis of high-dimensional categorical data, has the advantage over other cluster analysis techniques of allowing analysis of small samples with a large number of variables (MACHADO, 1997). Another advantage is that it easily reveals the heterogeneity present in the sample, since the degree of pertinence of each respondent is given by the conjunction of all the model's categorical variables (SAWYER et al., 2002).

We used the GOM 3 software to estimate the model parameters, which allowed characterizing the students' profiles and revealed the degree of pertinence of all the respondents in relation to those profiles.

We also applied the t-test for statistical analysis. According to Hair Junior et al. (2005), the t-test serves to assess the statistical significance between two sample means for a single dependent variable. It is considered a special case of ANOVA for two groups or levels of a treatment variable. For this analysis, we used the SPSS version 16.0 program, with significance of $\alpha=0.05$ and confidence interval of $95 \%$. 
In the next section we present and discuss the main results.

\section{PRESENTATION AND DISCUSSION OF THE RESULTS}

\subsection{CHARACTERIZATION OF THE RESPONDENTS}

About $64 \%$ of the respondents were females and $60 \%$ stated they were 25 years old or younger. Furthermore, $80 \%$ of the students said they were single and $85 \%$ stated they did not have children. Another relevant aspect is that more than $85 \%$ of the students were also working at the time of the study. This can be explained by the fact that the respondents were drawn only from evening study programs, which are mainly chosen by people who work day jobs. As to socioeconomic class, nearly $70 \%$ of the respondents fell in classes B2, C1 and C2 according to the Economic Classification Criterion ${ }^{1}$. Finally, with respect to household income, the majority (about 75\%) stated they had income of up to 10 times the minimum monthly wage.

\subsection{RELIABILITY OF THE SCALES}

To analyze the reliability of the scales, we calculated Cronbach's alpha, separately for each of the constructs (MALHOTRA, 2001). The Cronbach's alpha values are indicated in Table 3.

Table 3 - Reliability of the Scales

\begin{tabular}{c|c}
\hline Dimension & Cronbach's Alpha \\
\hline Cultural and symbolic influence & 0.751 \\
\hline Expected benefits & 0.821 \\
\hline Consumption and spending & 0.895 \\
\hline Adjustment to reality & 0.908 \\
Source: Survey data (2012) &
\end{tabular}

It can be seen that the scales of all the dimensions proposed had satisfactory reliability, because the Cronbach's alpha values were all greater than 0.75 , peaking at 0.908 for the adjustment to reality dimension. These results allow us to affirm that the scales adequately measured the constructs and that the results accurately reflect reality.

\subsection{DELINEATION OF THE PROFILES}

Since there is no standard procedure to determine the number of profiles, the decision on this number depends on the objective of the study. Because the GoM method allows

\footnotetext{
${ }^{1}$ This classification system contains classes E, D, C2, C1, B2, B1, A2 and A1, from bottom to top. It is determined by a combination of income, education level of the head of household and possession of appliances.
} 
obtained the desired number of profiles, we initially carried out applications with four, three and two profiles. The application of the model with three profiles was considered most satisfactory. These procedures are discussed in detail by Sawyer et al. (2002).

Although the profiles can be determined based on technical criteria, we defined them according to the "substantive significance" of the extreme profiles, i.e., for each new profile created, we verified the whether the changes observed could be justified from the theoretical standpoint (SAWYER et al., 2002, p. 760).

Therefore, we considered that a category $l$ of a variable $j$ would be characteristic of a profile $k$ if the ratio $\lambda_{k j l}$ and marginal frequency were greater than or equal to 1.50 . This arbitrary value appeared to do a good job of capturing the dominant characteristics of the extreme profiles.

\subsection{THE POSITIONING OF THE RESPONDENTS IN RELATION TO EACH PROFILE}

To verify how the respondents were positioned in relation to each of the profiles, by means of the GoM scores, we used the classification proposed by Sawyer et al. (2000). We reached three extreme profiles: 1, 2 and 3. Mixed profiles are those that although satisfying the criteria of a given profile, present some characteristics of another profile. For example, mixed profile 12 had predominance of characteristics of profile 1, but taking into consideration the parameters of the GoM method, had some pertinence to profile 2 . Respondents who did not fit in any of the profiles were considered "Amorphous", i.e., respondents equidistant to the extreme profiles, hence not having characteristics of any single profile.

Table 4 shows the distribution of the students according to the typology described above. Extreme Profile 1 was characterized based on 41 respondents (11.14\% of the sample), while Extreme Profile 2 was characterized based on 104 respondents ( $28.26 \%$ of the sample) and Extreme Profile 3 contained 41 respondents (11.14\% of the sample). Therefore, the delineation of the extreme profiles was based on 186 respondents (approximately $50 \%$ of the sample), who had all the characteristics of one of the three profiles. The mixed profiles are those that have most of the characteristics of a profile, but also have some characteristics of another one.

The results presented in Table 4 appear to confirm the existence of differentiated profiles among the business administration majors regarding the perception of higher education. Extreme Profile 1 is composed mainly of students from low-income backgrounds 
who in general agreed that higher education provides an opportunity to rise socially, obtain better professional opportunities, earn more money and be able to purchase more goods and services. However, these students reported the need to reduce their spending on food, clothes and accessories, health care, leisure activities such as travel, movies and restaurants, as well as electronic appliances, in order to pay school expenses. Furthermore, they often faced difficulties in keeping up with other students, making tuition payments and balancing work and school (jeopardizing their jobs), with a higher risk of having to take a leave of absence.

In contrast, the students categorized as having Profile 3 come from households with income higher than ten times the minimum monthly wage and belong to classes A1, A2 or B1. They had a different perception than the students with the first profile, because they disagreed that a college degree provides a chance to rise socially, have better professional opportunities and improve their standard earnings. They stated they do not have to reduce spending on food, leisure and electrical appliances to meet their school expenses. Finally, the students with Profile 2 have an intermediate perception, i.e., they typically took a neutral position on the questions.

Table 4 - Distribution of Students, According to the Predominance of Profiles

\begin{tabular}{|c|c|c|c|}
\hline Description of the extreme profiles & $\begin{array}{l}\text { Predominance of the } \\
\text { profile }\end{array}$ & $\begin{array}{l}\text { Absolute } \\
\text { frequency }\end{array}$ & $\begin{array}{c}\text { Percentage } \\
(\%)\end{array}$ \\
\hline \multirow{4}{*}{$\begin{array}{l}\text { Extreme Profile 1: Students from } \\
\text { families in classes C and D who agreed } \\
\text { partially or totally with the statements } \\
\text { presented in table } 2\end{array}$} & Predominant 1 & 41 & 11.14 \\
\hline & Mixed 1 with 2 & 39 & 10.60 \\
\hline & Mixed 1 with 3 & 8 & 2.17 \\
\hline & SUBTOTAL & 88 & 23.91 \\
\hline \multirow{4}{*}{$\begin{array}{l}\text { Extreme Profile 2: Students who } \\
\text { partly agreed or were neutral regarding } \\
\text { the statements presented in table } 2\end{array}$} & Predominant 2 & 104 & 28.26 \\
\hline & Mixed 2 with 1 & 40 & 10.87 \\
\hline & Mixed 2 with 3 & 20 & 5.43 \\
\hline & SUBTOTAL & 164 & 44.56 \\
\hline \multirow{4}{*}{$\begin{array}{l}\text { Extreme Profile 3: Students from } \\
\text { families in classes A and B who totally } \\
\text { or partly disagreed with the statements } \\
\text { presented in table } 2\end{array}$} & Predominant 3 & 41 & 11.14 \\
\hline & Mixed 3 with 1 & 7 & 1.90 \\
\hline & Mixed 3 with 2 & 29 & 7.88 \\
\hline & SUBTOTAL & 77 & 20.92 \\
\hline \multirow{3}{*}{$\begin{array}{l}\text { Amorphous: Students who did not fit } \\
\text { in any profile }\end{array}$} & Amorphous & 39 & 10.60 \\
\hline & SUBTOTAL & 39 & 10.60 \\
\hline & Total & 368 & 100.00 \\
\hline
\end{tabular}

Source: Survey data (2012) 


\subsection{DIFFERENCES BETWEEN HIGH AND LOW INCOME GROUPS}

To achieve the proposed objectives, we applied the t-test (a type of analysis of variance) to check for significant differences between the means of the four dimensions presented in table 1. For this purpose, we divided the sample of 368 students into two groups: one with students belonging to economic classes A1, A2 and B1; and the other with students belonging to classes B2, C1, C2, D and E, to check whether it is possible to state there are differences in perception regarding higher education. Despite criticism and controversy regarding that classification, the cross-sectional criterion for low-income individuals was based on studies by Parente, Barki and Kato (2005), Spers and Wright (2006) and Veloso and Hildebrand (2006). The results of the test are shown in Table 5.

Table 5 - Results of the T-Test

\begin{tabular}{c|c|c|c|c|c|c}
\hline \multicolumn{2}{c}{ Test value } \\
\hline Dimensions & t-value & $\begin{array}{c}\text { Degrees of } \\
\text { freedom }\end{array}$ & $\begin{array}{c}\text { Significance } \\
\text { (two-tail) }\end{array}$ & $\begin{array}{c}\text { Diff. from } \\
\text { mean }\end{array}$ & $\begin{array}{c}\text { 95\% confidence interval for } \\
\text { the difference }\end{array}$ \\
\cline { 4 - 7 } & & & & Below & Above \\
symbolic influence & 2.535 & 409 & 0.012 & 0.12430 & 0.02792 & 0.22069 \\
\hline $\begin{array}{c}\text { Expected benefits } \\
\text { Cultural and }\end{array}$ & 2.629 & 409 & 0.009 & 0.17789 & 0.04490 & 0.31088 \\
\hline $\begin{array}{c}\text { Relevance } \\
\text { Adjustment to } \\
\text { reality }\end{array}$ & 5.319 & 409 & 0.000 & 0.48361 & 0.30487 & 0.66325 \\
\hline
\end{tabular}

Source: Survey data (2012)

From the results obtained, we can state that statistical evidence exists that the perception of students belonging to classes A1, A2 and B1 is different than the perception of those belonging to classes $\mathrm{B} 2, \mathrm{C} 1, \mathrm{C} 2, \mathrm{D}$ and $\mathrm{E}$ in three of the four dimensions: cultural and symbolic influence, expected benefits and relevance. This indicates that cultural and symbolic questions regarding enrollment in a college course, together with questions of the benefits and relevance that higher education occupies in the respondents' consumption priorities, are the most significant to distinguish the perception of the students taking into consideration their economic class and income. This result corroborates the findings from applying the GoM technique, according to which the income and economic class variable serves to differentiate profiles of business administration students regarding perception of the course.

The results of the GoM method and t-test, which indicate that both economic class and income serve as differentiators, highlight two fundamental points. In the first place, income 
can be considered a constraint on consumption, since the students in the lower income group stated they had to reduce spending on food, cars and leisure to be able to meet their school expenses. However, in the second place, as discussed in the literature review on the symbolic and cultural aspects involving consumption, there is a social construction of meanings among the individuals.

Therefore, it is necessary to consider that the symbolic universe revealing the students' perceptions of entering a teaching institution can be thought of as a space for meetings that enable forms of relationships and concrete social exchanges in a circle of social interaction, marked by various questions, such as coexistence, interaction, socialization, association, belonging and manifestations of world views, lifestyles, desires and dreams (PORTILHO, 2009).

Moreover, an expectation can be perceived by students drawn from the lower economic strata regarding professional growth, and mainly increased personal income, by obtaining a college degree. In the same sense, besides seeing higher education as an opportunity to rise economically, it also is seen as a way to achieve higher status and valorization by colleagues, and as such represents a personal conquest. In this respect, it can be considered that enrollment in an undergraduate business administration course permits these students to gain greater insertion in today's society of consumption.

In line with the findings of various authors on the cultural perspective of consumption discussed previously, the results appear to confirm that it is not suitable to consider any group of consumers, in this case consumers of higher education, as a homogeneous class, obedient and faithful to fixed standards, because these individuals are constantly passing between different spheres, realities, levels and explanatory systems.

In the same sense, as stressed by Slater (2002), all consumption involves meaning. This also applies to consumption of education, mainly when verifying that these forms of consumption, in being articulated in daily life, gain meanings and are shared by the members of groups. In other words, the meanings and rituals of consumption demarcate the categories and classifications that compose the social order. Complementarily, these meanings are used in people's everyday practices to construct and maintain social relations.

\section{FINAL CONSIDERATIONS}

In light of the results presented, it is useful to return to the questions that motivated this work. In doing so, it can be said that undergraduate business administration students have 
different perceptions of the symbolic elements of higher education. In particular, those from lower income backgrounds see higher education as an opportunity for social ascension, greater confidence and self-esteem, besides considering college entrance as a personal conquest that enables greater valorization within the family and circle of friends, and higher status in society as a whole.

With respect to the perceived benefits, the students surveyed, especially those from lower economic classes, agreed that a college degree will give them better job and professional growth opportunities and higher income. With respect to the articulation between consumption and college study, the poorer students reported they have to limit their spending on food, clothes and leisure in order to pay their school expenses. Finally, the main finding is that there is a difference in perceptions between lower versus higher income students, as reported in the previous sections.

These results have some implications for related fields of study, primarily in the field of research into consumption, more precisely the consumption behavior of low-income individuals. Individuals in this group, who until recently appeared to be at the margin of the educational process and "invisible" in market surveys (BARROS, 2006), have a different construction of meanings, based on distinctive relationships with the institution, classmates, work colleagues, family members and other actors in a broad circle of social interaction. In the second place, the results contribute to discussions about business administration courses, involving students' perception of the course, the teaching institution and the career and profession of business manager.

In the third place, the findings, while adding to those of other studies conducted about the quality of administration courses (SOUKI; PEREIRA, 2004; NICOLAO; SPARTEL, 2004; CODA; SILVA, 2004; VELUDO-DE-OLIVEIRA; IKEDA, 2006; ARAÚJO et al., 2010; MAINARDES; DOMINGUES, 2010; TONTINI; WALTER, 2011; LOURENÇO; KNOP, 2011; MENDONÇA et al., 2012), also serve as a counterpoint in the sense of showing the existence of different student profiles and that the perception of these profiles can be disparate. The study also sheds light on the question of the trajectory of business administration study, which according to statistics has expanded considerably in recent years, becoming a highly competitive "market" with complex competition aspects.

Furthermore, the results of this study can guide managers of higher education institutions who want to better understand their actual and potential students, and 
consequently implement more suitable and effective communication and relationship strategies, able to attract and serve students of different economic strata.

The results can also be important to professionals responsible for planning and coordinating teaching projects, curriculums and activities that can be sensitive to these different student profiles. In a country like Brazil, with hugely diverse local realities, this concern cannot be overlooked by college administrators, much less by curriculum formulators and course coordinators.

With respect to the methodology, we can state that use of the Grade of Membership (GoM) method proved adequate and pertinent to the research objective, leading to consistent responses to the questions that motivated this study. The GoM method is based on fuzzy logic theory and is an advance on other techniques normally used to identify profiles or segments of consumers. In turn, the consultation of the literature regarding consumption in a cultural and symbolic perspective, although not usual to support discussion of results in this field of study, was revealing to understand the question of meanings attributed by students to the business administration course.

There are some limitations of this study that should be mentioned. Firstly, we focused only on undergraduate business administration students attending night classes at five private institutions in a large Brazilian city. Another limitation is that the sample of these students was non-probabilistic and chosen by convenience. We did not include students from public universities or those with other majors, such as the hard sciences, or those studying public as opposed to business administration.

Furthermore, there is always the difficulty of formulating a suitable survey instrument to elicit responses to highly complex questions, as is the case of the construction of meanings by undergraduate college students. Another issue that cannot be overlooked is the occurrence of the social desirability bias in surveys of this type (MOHR; WEBB, 2001). This bias arises when the answers are not based on what the respondents really feel, but rather on what they believe is socially appropriate. Based on the nature of the questions posed, the social desirability bias was likely present to some extent in this study.

We can also make some suggestions for further and complementary studies that can shed more light on the themes addressed here. One would be to expand the cross-section of students interviewed. Even though our sample was drawn from five institutions of different sizes, all of them were private and all the students were taking night classes. Hence, there is 
room to investigate the same questions among daytime students or those attending public institutions. Also, since $80 \%$ of the sample was composed of students who also held paying jobs, it would be interesting to assess the perception of students who do not have any professional experience. Another interesting issue would be to study other contexts of administration, such as public administration, and compare the results with the perception of professionals who work at teaching institutions, such as professors, course coordinators and academic directors, among others.

Finally, we should stress that the objectives of this study were far-ranging, and the results can be controversial and subject to challenges. Our intention is not to "foreclose" the questions that motivated this study, much less offer a set of correct responses to existing questions and the new ones that arose during the work, which were many. We hope our findings lead to further discussions among researchers of the questions addressed here and of others, without attempting to find "absolute truths".

\section{REFERENCES}

ALVES, L. C.; LEITE, I. C.; MACHADO, C. J. Perfis de saúde dos idosos no brasil: análise da pesquisa nacional por amostra de domicílios de 2003 utilizando o método grade of membership. Cadernos de Saúde Pública, v. 24, n. 3, p. 535-546, 2008.

AQUINO, R. D.; TOMASSINI, R. O Consumo para os estudantes de administração: uma aplicação da teoria do núcleo central de representações sociais. In: ENCONTRO NACIONAL DA ASSOCIAÇÃO NACIONAL DE PÓS-GRADUAÇÃO E PRESQUISA EM ADMINISTRAÇÃO (ENANPAD), 33., 2009, São Paulo (SP). Anais... São Paulo: ANPAD, 2009.

ARAUJO, S. P. M. et al. Fatores de escolha da carreira de administração e da instituição de ensino. Administração: Ensino e Pesquisa, v. 11, n. 2, p. 163-190, abr./jun. 2010.

BABBIE, E. Métodos de pesquisa de survey. Belo Horizonte: Editora UFMG, 1999.

BARBOSA, L. Apresentação. In: BARBOSA, L.; CAMPBELL, C. (Orgs.). Cultura, consumo e identidade. Rio de Janeiro: Editora FGV, 2006.

BARBOSA, L.; CAMPBELL, C. O Estudo do consumo nas ciências sociais contemporâneas. In: BARBOSA, L. ; CAMPBELL, C. (Orgs.). Cultura, consumo e identidade. Rio de Janeiro: Editora FGV, 2006.

BARROS, C. F. A "invisibilidade" do mercado de baixa renda nas pesquisas de marketing: as camadas populares consomem ou sobrevivem? In: ENCONTRO DE MARKETING (EMA), 2., 2006, Rio de Janeiro (RJ). Anais... Rio de Janeiro: ANPAD, 2006.

BARTHOLOMEW, D. J. et al. The analysis and interpretation of multivariate data for social scientists. Boca Raton: Chapman \& Hall/CRC, 2002. 
BATISTA-DOS-SANTOS, A. C. et al. Uma escuta ao alunado de administração: suas concepções de administração e administrador à luz de uma abordagem crítica.

Administração: Ensino e Pesquisa, v. 12, n. 2, p. 163-190, abr./jun. 2011.

BERGAMO, F. V. M.; GIULIANI, A. C.; GALLI, L. C. L. A. Modelo de lealdade e retenção de alunos para instituições do ensino superior: um estudo teórico com base no marketing de relacionamento. Brazilian Business Review - BBR, v. 8, n. 2, p. 43-67, abr./jun. 2011.

BOMTEMPO, M. S.; SILVA, D.; FREIRE, O. B. L. Motivos da escolha do curso de administração de empresas por meio da modelagem de equações estruturais. Pretexto, v. 13, n. 3, p. 108-129, 2012.

BORINI, F. M.; SILVA, A. L. L.; PONCHIO, M. C. valor percebido pelo consumidor de curso superior em administração por escolas direcionadas para baixa renda e alta renda.

Revista de Administração da UNIMEP, v. 7, n. 1, p. 122-137, 2009.

CAETANO, A. J.; MACHADO, C. J. Consistência e identificabilidade no modelo de grade of membership: uma nota metodológica. Revista Brasileira de Estudos Populacionais, v. 26, n. 1, p. 145-149, 2009.

CAMARGOS, M. A. et al. Motivos da escolha, percepções e perspectivas de alunos de IES privadas de Minas Gerais. E-civitas, v. 1, n.1, p. 1-21, 2008.

CARDOSO, L. O. et al. Uso do método grade of membership na identificação de perfis de consumo e comportamento alimentar de adolescentes do Rio de Janeiro, Brasil. Cadernos de Saúde Pública, v. 27, n. 2, p. 335-346, 2011.

CERQUEIRA, C. A.; SAWYER, D. O. Tipologia e características dos municípios brasileiros. In: ENCONTRO NACIONAL DE ESTUDOS POPULACIONAIS. 14, 2004, Caxambu (MG). Anais... Caxambu: ABEP, 2004.

CHURCHILL JUNIOR, G. A paradigm for developing better measures of marketing constructs. Journal of Marketing Research, v. XVI, p. 64-73, 1979.

CODA, R.; SILVA, D. Sua escola de administração é uma excelente escola para se estudar? Descobrindo dimensões da satisfação de alunos em cursos de Administração: uma contribuição metodológica. In: ENCONTRO NACIONAL DA ASSOCIAÇÃO NACIONAL DOS PROGRAMAS DE PÓS-GRADUAÇÃO E PESQUISA EM ADMINISTRAÇÃO (ENANPAD), 28., 2004, Curitiba (PR). Anais... Curitiba: ANPAD, 2004.

DESJEUX, D. O consumo: abordagens em ciências sociais. Maceió (AL): EDUFAL, 2011.

FALCÃO, D. F.; ROSA, V. V. Um estudo sobre a motivação dos universitários do curso de Administração: uma contribuição para gestão acadêmica no âmbito público e privado. In: ENCONTRO NACIONAL DA ASSOCIAÇÃO NACIONAL DOS PROGRAMAS DE PÓSGRADUAÇÃO E PESQUISA EM ADMINISTRAÇÃO (ENANPAD), 32., 2008, Rio de Janeiro (RJ). Anais... Rio de Janeiro: ANPAD, 2008.

FISCHER, T. M. D. A difusão do conhecimento sobre organizações e gestão no Brasil: seis propostas de ensino para o decênio 2000/2010. In: ENCONTRO NACIONAL DA ASSOCIAÇÃO NACIONAL DOS PROGRAMAS DE PÓS-GRADUAÇÃO E PESQUISA 
EM ADMINISTRAÇÃO (ENANPAD), 28., 2000, Curitiba (PR). Anais... Curitiba: ANPAD, 2000.

HAIR JUNIOR, J. F. et al. Análise multivariada de dados. 5. ed. Porto Alegre: Bookman, 2005.

LOMBARDI, M. F. S.; ARAÚJO, B. F. B.; TEIXEIRA, M. L. M. Os estudantes de graduação em administração de empresas e seus valores básicos: um estudo em duas universidades da Cidade de São Paulo. In: ENCONTRO DE ENSINO E PESQUISA EM ADMINISTRAÇÃO E CONTABILIDADE (ENEPQ), 2., 2009, Curitiba (PR). Anais... Curitiba: ANPAD, 2009.

LOURENÇO, C. D. S.; KNOP, M. F. T. Ensino superior em administração e percepção da qualidade de serviços: uma aplicação da escala SERVQUAL. Revista Brasileira de Gestão de Negócios, v. 13, n. 39, p. 219-233, 2011.

MAINARDES, E. W.; DOMINGUES, M. J. C. S. Qualidade de cursos de administração e instituições de ensino superior em Joinville - SC: um estudo sobre fatores relacionados ao mercado de trabalho na percepção dos alunos. Revista Brasileira de Gestão de Negócios, v. 12, n. 35, p. 208-223, 2010.

MCCRACKEN, G. Cultura e consumo II: mercados, significados e gerenciamento de marcas. Rio de Janeiro: Mauad, 2012.

MACHADO, C. J. Perfis de morbi-mortalidade infantil no Estado de São Paulo, 1994: uma aplicação de grade of membership à análise de causas múltiplas de morte. 1997. Dissertação (Mestrado) - CEDEPLAR/UFMG, Belo Horizonte (MG), 1997.

MALHOTRA, Naresh. Pesquisa de marketing. Porto Alegre: Bookman, 2001.

MENDONÇA, C. M. C. et al. Análise da importância, desempenho e influência de serviços na retenção de alunos em curso de Administração. Revista Gestão e Planejamento, v. 13, n. 2, p. 294-314, 2012.

MILLER, D. Teoria das compras: o que orienta as escolhas dos consumidores. São Paulo: Nobel, 2002.

MIRANDA, N. A.; SILVA, D. Expectativas profissionais dos alunos do ensino superior noturno de administração de empresas. Revista Lumem, v. 9, n. 20, jan./abr. 2003.

MOHR, L. A.; WEBB, D. J. Do consumers expect companies to be socially responsible ? the impact of corporate social responsibility on buying behavior. Journal of Consumer Affairs, v. 35, p. 45-62, 2001.

MORGAN, D. L. Focus groups as qualitative research. Thousand Oaks, CA: Sage, 1997.

NICOLAO, L.; SPARTEL, L. B. Julgamentos pós-escolha do curso de administração: o papel da qualidade percebida, da satisfação e do arrependimento e os seus comportamentos subseqüentes. In: ENCONTRO NACIONAL DA ASSOCIAÇÃO NACIONAL DOS PROGRAMAS DE PÓS-GRADUAÇÃO E PESQUISA EM ADMINISTRAÇÃO (ENANPAD), 29., 2005, Brasília (DF). Anais... Brasília: ANPAD, 2005. 
PARENTE, J. G.; BARKI, E. E. R.; KATO, H. T. Consumidor de baixa renda: desvendando as motivações no varejo de alimentos. In: ENCONTRO NACIONAL DA ASSOCIAÇÃO NACIONAL DOS PROGRAMAS DE PÓS-GRADUAÇÃO E PESQUISA EM ADMINISTRAÇÃO (ENANPAD), 29., 2005, Brasília (DF). Anais... Brasília: ANPAD, 2005.

PEREIRA, D. R. M.; PINTO, M. R. Perfis de empresas varejistas quanto a adoção de práticas de responsabilidade social. Revista de Administração (USP), São Paulo, v. 39, n. 2, p. 153 $163,2004$.

PORTILHO, F. Sociabilidade, confiança e consumo na feira de produtos orgânicos. In: BARBOSA, L.; PORTILHO, F.; VELOSO, L. Consumo: cosmologias e sociabilidades. Rio de Janeiro: Mauad X, 2009.

PRAHALAD, C. K. A riqueza na base da pirâmide: como erradicar a pobreza com o lucro. Porto Alegre: Bookman, 2005.

PRAHALAD, C. K.; HAMMOND, A. Serving the world's poor. Harvard Business Review, v. 80, n. 9, sep. 2002.

PINTO, M. R.; PEREIRA, D. R. M.; SANTOS, L. L. S. Caracterização de perfis de consumidores quanto à disposição de adoção de produtos e serviços baseados em tecnologia a partir da utilização do método de grade of membership (GoM). REAd, v. 13, n. 4, 2007.

SAWYER, D. O. et al. Caracterização dos tipos de doadores de sangue em belo horizonte: heterogeneidade do homogêneo. In: ENCONTRO DE ESTUDOS POPULACIONAIS, 12., 2000, Caxambu (MG). Anais... Caxambu: ABEP, 2000.

SAWYER, D. O.; LEITE, I. C.; GARCIA, R. A. Perfis de utilização de serviços de saúde no Brasil. Ciência \& Saúde Coletiva, v. 7, n. 4, p. 757-76, 2002.

SILVA, W. R.; MACHADO, M. A. V. Motivos que levam os alunos a cursar graduação em administração: um estudo nas instituições públicas e privadas do estado da Paraíba. In:

ENCONTRO NACIONAL DA ASSOCIAÇÃO NACIONAL DOS PROGRAMAS DE PÓSGRADUAÇÃO E PESQUISA EM ADMINISTRAÇÃO (ENANPAD), 30., 2006, Salvador (BA). Anais... Salvador: ANPAD, 2006.

SLATER, D. Cultura do consumo e modernidade. São Paulo: Nobel, 2002.

SOUKI, G. Q.; PEREIRA, C. A. Satisfação, motivação e comprometimento de estudantes de administração: um estudo com base nos atributos de uma instituição de ensino superior. In: ENCONTRO NACIONAL DA ASSOCIAÇÃO NACIONAL DOS PROGRAMAS DE PÓS-GRADUAÇÃO E PESQUISA EM ADMINISTRAÇÃO (ENANPAD), 28., 2004, Curitiba (PR). Anais... Curitiba: ANPAD, 2004.

SPERS, R. G.; WRIGHT, J. T. C. Mercado de bens populares no brasil: desempenho e estratégia das empresas. In: ENCONTRO NACIONAL DA ASSOCIAÇÃO NACIONAL DOS PROGRAMAS DE PÓS-GRADUAÇÃO E PESQUISA EM ADMINISTRAÇÃO (ENANPAD), 30., 2006, Salvador (BA). Anais... Salvador: ANPAD, 2006.

TAM, N. P.; BORGES, A. A segmentação de mercado a partir do método fuzzy logic: uma alternativa metodológica para o problema de superposição dos Segmentos na Classificação. 
In: ENCONTRO NACIONAL DA ASSOCIAÇÃO NACIONAL DOS PROGRAMAS DE PÓS-GRADUAÇÃO E PESQUISA EM ADMINISTRAÇÃO (ENANPAD), 30., 2006, Salvador (BA). Anais... Salvador: ANPAD, 2006.

TONTINI, G.; WALTER, S. A. Antecedentes da qualidade percebida de um curso de administração: uma abordagem não linear. Revista Brasileira de Gestão de Negócios, v. 13, n. 40, p. 264-280, 2011.

VELOSO, A. R.; HILDEBRAND, D. F. N. A Criança no ambiente varejista: estudo exploratório na base da pirâmide. In: ENCONTRO DE MARKETING (EMA), 2., 2006, Rio de Janeiro (RJ). Anais... Rio de Janeiro: 2006.

VELUDO-DE-OLIVEIRA, T. M.; IKEDA, A. A. Valor em serviços educacionais. RAEEletrônica, v. 5, n.2, jul./dez. 2006. 